\title{
The Role of Law in Corporate Accountability
}

\author{
Stuart Kirsch
}

\begin{abstract}
This special issue addresses the role of law in corporate accountability. Case studies reference people affected by asbestos in Italy, a coal company anticipating closure in Colombia, and both activists and human rights lawyers concerned with the impacts of mining in Ecuador. The afterword considers the significance of temporality in the law, including limits on retrospective claims and efforts to expand the prospective reach of both the law and state policy. It describes the perspectival character of the law in which the forum determines how the underlying facts are seen. It examines how responsibility, against a backdrop of distributed agency, is conceptualized by shortening or expanding chains of liability. It also points to the need for stronger connections between the anthropology of suffering and the discipline's ethical turn. Finally, it suggests that the legal claims discussed here are aspirational in the sense of describing how the world ought to be.
\end{abstract}

Keywords: corporations, global ecumene, law, responsibility, temporality

The contributors to this edited collection in the Journal of Legal Anthropology examine the strong conviction, shared by people as disparate and dispersed as the residents of a factory town in Italy, rural peasants in Colombia, and both community activists and human rights lawyers in Ecuador, that corporations have responsibilities to their neighbours. In all four cases, these relationships are framed in terms of legal rights and obligations. In the first case, not only were the workers in an asbestos factory in Italy stricken by lung disease, but the people living in the nearby town were also sickened by their exposure. The former received compensation through civil claims that addressed workplace injuries, but the latter remain uncompensated due to the statute of limitations on criminal violations (Loher this issue). In the second case, a mining company anticipating closure of two coal mines in Colombia sought to disentangle itself from the surrounding communities. 
However, the people living nearby and affected by the project insisted that the company had an ongoing responsibility to provide them with economic opportunities (Knöpfel, this issue). In the third case, transnational litigation against a mining company operating in the Andes resulted in a settlement that provided financial compensation to the claimants. But there was no public reckoning of the company's liability for human rights violations against anti-mining protestors, and the case failed to establish a legal precedent that would reduce the likelihood of subsequent offenses (Lindt, this issue). In the final example, lawyers and social movements in Ecuador have mobilized new legal provisions intended to prevent future harm. Here the responsibilities of the state to protect its citizens and nature against corporate malfeasance are imagined in new ways (Affolter, this issue). Collectively, the articles explore the role of law in managing relations between corporations, communities, and the state, including inevitable challenges and shortcomings in its application.

Angela Lindt describes how human rights lawyers in Ecuador were disappointed by the results of legal proceedings against a British mining company in the United Kingdom because the case was settled out of court. They were critical of the settlement for two reasons. First, while their clients received financial compensation, the corporation was not compelled to apologize or even acknowledge its complicity in human rights violations. The terms of the settlement also barred the plaintiffs from continuing to speak out about the case. This made it look as though the claimants' speech had been bought, which was especially vexing for the local activists who participated in the proceedings. The second source of frustration stemmed from the fact that the case was settled out of court and consequently failed to achieve their goal of deterring future human rights violations. In short, the action failed to bring about structural change. This is a very telling point, as it reveals that the motives of the plaintiffs exceeded personal and even community interests; rather, the scope of their concerns reveals a broader commitment to social justice. Whereas efforts to undercut or delegitimate social justice claims often assert they are motivated primarily by self-interest, the plaintiffs' disapproval of the out-of-court settlement indicate otherwise.

Lindt's work points to a general pattern. Most lawsuits against corporations that are not summarily dismissed are resolved through out-of-court settlements. Rather than the courtroom denouement that dominates public representation of legal proceedings, it is more commonly a behind-the-scenes paper chase that dictates the outcome, not 
verdicts rendered by judges or juries. Once a case makes it past the initial hurdles-that a proper civil or criminal complaint has been made, the determination that the court has jurisdiction to rule on the matter, and that efforts by the defence to undermine both of these have been rebuffed-the next phase in the proceedings is typically discovery, in which each side is able to compel the other to provide documents pertaining to the case. Given the potential reputational costs of disclosure, corporations are generally reluctant to make their records available for scrutiny. Thus the threshold for settlement often has less to do with the adjudication of the actual claims than a judgment compelling the company to release all of its relevant records, which is a much lower barrier (see Bebchuk 1984: 413). ${ }^{1}$ This is one of the few structural advantages available to plaintiffs in legal proceedings. It is not uncommon for cases to be settled out of court prior to disclosure, as the desire to avoid releasing internal documents leads the corporation to cut its losses. In contrast, most other structural factors, including the costs of going to trial, and the risk of receiving an adverse judgement, favour the corporation, which allows it to impose limitations on settlement agreements, including confidentiality.

The settlement of human rights cases presents the plaintiffs with a double-bind in the sense of having to accept half-measures-receiving compensation but not forcing an admission of guilt or a public reckoning-whereas the corporation can easily spin the overall narrative by claiming that it was forced to settle to protect its reputation and limit future risks to its interests, without ever having to take responsibility for wrong-doing. Payments to plaintiffs can also have a corrosive effect on community solidarity as a result of unequal distribution and the exclusion of some who may feel entitled to recompense (see ArellanoYanguas 2013). These settlements do not necessarily contribute to the reduction of similar harms in the future, which is the ultimate aim of human rights law (Kirsch 2018: 87). However, they can affect corporate behaviour in a general sense by establishing new norms and expectations (see Kirsch 2014a). But it remains an open question as to whether compensation can ever make up for what has been lost (Kirsch 2001a; Torpey 2006), especially when limited to monetary form. Despite these shortcomings, the lack of alternative weapons of the weak helps to explain why communities that have been wronged continue to turn to the courts for justice (see Eckert et al. 2012).

David Loher takes up related questions about the differential treatment of persons harmed by an asbestos manufacturing plant in Italy. Injuries to workers were treated in a transactional fashion under civil 
law. In contrast, health impacts from the factory on the people living in the surrounding area were addressed through criminal proceedings. The former received compensation, but the latter did not as a result of the statute of limitations. The account lays bare what might be described as the perspectival character of the law in the sense that harm caused by corporations is perceived and treated differently according to the relationship between the corporation and the affected parties, whether employees of the manufacturing plant or the residents living nearby who were exposed to harmful asbestos fibres. This is a general tendency within the law, in which the same or similar circumstances are treated differently across legal forums and alterative bodies of law. It is especially pronounced in the context of international legal proceedings, in which radically different outcomes are on offer. This is why lawyers representing both plaintiffs and corporations routinely engage in 'forum shopping' even though the practice is generally regarded as inappropriate and frequently barred by statute or the legal requirement that domestic avenues for adjudication must be exhausted before turning elsewhere. The previous case of bringing human rights violations to the courts in the UK against a corporation operating in Ecuador is an example of this. A comparable dynamic is evident when corporations move their complaints from domestic legal contexts to arbitration panels established and regulated by various treaties between states, including proceedings overseen by the International Center for the Settlement of Investment Disputes (ICSID) at the World Bank, which regularly hears cases from corporations against states for imposing restrictions on their operation (Broad 2015; see Kirsch and Moore 2016). ${ }^{2}$ In general, the vantage point of the court-including relevant case law, precedents, rules of evidence, and possible penalties-determine the outcome as much or more than the facts of the matter. The claim that the law must be applied consistently in order to be fair ignores its underlying perspectival character, especially when legal cases travel across borders.

Time and temporality enter into these cases in important ways, as Loher describes. The courts refused to recognize the health impacts of the manufacturing plant on the people living in town because of the time that elapsed before the symptoms emerged, which affected their ability to file claims before the statute of limitations expired. There are means by which the law may prospectively anticipate future health effects, as in the recent settlement of a lawsuit against the German company Bayer for the health impacts of the toxic herbicide Roundup, in which funds will be set aside in anticipation of future claims. But the people living in town were time barred from making retroactive claims. 
The application of the law is not neutral in its relationship to time, although recent efforts in Ecuador and elsewhere attempt to overcome this imbalance, as I discuss below.

A related question has to do with the moment the company recognized that casual exposure to asbestos was likely to cause harm to the people living nearby. Did the legal proceedings address how much time elapsed between the company's recognition that it was causing harm and its eventual closure? From that moment forward, the responsibility of the corporation shifts in character, perhaps analogous to the distinction between charges of manslaughter and murder. But it is important to point out that such recognition is often deliberately forestalled or delayed in corporate efforts to defer responsibility for as long as possible (Kirsch 2014a). This too is a special kind of culpability that merits careful attention even when it is not adequately addressed by the law. In such circumstances, legal anthropologists and others, including media and civil society groups, have an important role to play in identifying 'blind spots' in the handling of such matters, and may even encourage modification of the law to help close such gaps. Thus Loher's work on the shortcomings and inconsistencies of the law can be understood as a mode of diagnosis upon which lawmakers might act.

Laura Knöpfel also examines the relationships between corporations and persons. She draws on Emmanuel Levinas' characterization of ethics as 'facework'. Given the treatment of corporations as jural persons, and the resulting conceptions of corporate personhood (Kirsch 2014b), Knöpfel suggests that interactions with corporations should also be seen as ethical relationships involving facework. ${ }^{3}$ This is distinct from the iconic chief executive officer who stands in for the corporation as a whole (see Bose and Lyons 2010; Rajak 2014). Instead she focuses on interpersonal interactions in which corporate employees become the public face of the organization. ${ }^{4}$ By extension, this raises questions about their ethical responsibilities when they engage with individuals harmed by their employer. Presumably they must develop some form of rationale for their willingness to work for a corporation that causes harm, such as the argument that people who smoke cigarettes have the right to make that choice (Benson 2010), or that mining projects provide benefits in the form of sustainable development that offset their environmental impacts (Affolter, this issue; Kirsch 2010). It would be valuable to have a deeper and comparative understanding of how individuals who work for such companies understand their ethical responsibilities and complicities (see Kirsch 2020). Examining these 
relationships may require piercing this other form of the corporate veil, which conceals the ethical face of corporate employees.

Finally, Laura Affolter examines how people living in Intag, Ecuador, the site of a proposed mining project, call upon the state to protect their future interests. This is in keeping with constitutional and legal reforms that invoke the responsibility of the state to protect against potential harm. These reforms address the bias in the law towards retroactive relief, as discussed above, by providing new resources under the rubric of buen vivir, or the ethics of a good life. This applies equally to concerns about the environmental impacts of mining and recognition of the rights of nature, which is part of a larger project of cosmopolitics that seeks to incorporate the interests of other-than-human persons (de la Cadena 2010). But as Affolter appropriately insists, these cases are also about the unrealized potential of the state as an agent with duties to protect its residents and the environment. Consequently, the state rather than the law becomes the means for addressing questions about the future, although it is through legal innovation that this becomes possible.

These articles also raise questions about distributed agency. Eckert and Knöpfel (this volume) invoke Marilyn Strathern's (1996) discussion of cutting the network, in particular the tendency for Euroamericans to shorten social networks in the context of property claims, although these networks may be expanded in length in other contexts (see Kirsch 2001b). The articles in this special issue suggest that assigning responsibility for particular outcomes also involves cutting the network. This process is predicated on the identification of singular agents that can be held accountable even in complex contexts involving multiple actors and materialities that have also shaped the outcome (see Deoanacă 2020). This suggests the importance of recognizing that chains of causality and responsibility can be manipulated to achieve certain outcomes. They may also be backdated in time to before the specific event in question, as when the party responsible for constructing a road is blamed for a fatal car accident (Kirsch 2001b), or when the manufacturer of handguns is held accountable for a shooting (Benson 2014). These claims also shift responsibility from one kind of agent, the driver of the automobile or the person who pulled the trigger, to other kinds of actors, or actants, including the parties responsible for the dangerous infrastructure or the manufacturer of the weapon that was discharged. Attributions of responsibility are mobile and manipulable resources rather than fixed or given by the events themselves. 
The underlying question of corporate accountability that runs through these articles also illuminates the debate between the practitioners of 'dark anthropology' (Ortner 2016) who focus on 'suffering subjects' and those calling for an 'anthropology of the good' (Robbins 2013) as part of the discipline's ethical turn. In contrast to choosing sides, the case studies point to the necessary connection between the two: the importance of keeping ethical systems and responsibility in mind when examining actions that result in harm, including the consequences of corporate decision-making. The anthropology of suffering tends to emphasize materiality and embodied experience, while the anthropology of the good is ideational and aspirational. The articles in this special issue demonstrate that an anthropology of one without the other is insufficient. In the context of corporate social responsibility, for example, it is important not only to examine ethics and intentions, but also the material and embodied outcomes of such policies and practices. This also applies to the domain of human rights as discussed in these articles, an ethical formulation that is meant to forestall future harm.

What do the articles presented here tell us about the law and the anthropology of legal responsibility in the global ecumene? In their stellar introduction, Eckert and Knöpfel point to the moral and legal responsibilities of corporations to communities even when the underlying relationships are stretched across international borders. We see from the contributions to this collection that the courts do not dispense social or environmental justice but instead provide financial recompense. This suggests that in addition to the juridification of politics, out of court settlements typically expand the monetization of politics, much as the US Supreme court notoriously equated corporate spending with free speech. The settlements rarely hurt the corporation as much as the plaintiffs have been harmed. They are infrequently accompanied by the apology and acknowledgement of responsibility that plaintiffs seek. And as Lindt shows us, settlement always equals compromise. The attention to these questions aligns with other trends in anthropological theory, including the shift from a focus on states to the corporation (see Benson and Kirsch 2010). Yet the state does not disappear entirely from the picture, and may be paramount as the agent capable of shifting legal recourse towards the prevention of future harm in contrast to the law's predilection to address harm after has it occurred. These discussions also indicate the perspectival character of the law, in which the forum shapes how the underlying facts are viewed, which is especially important in the context of international legal proceedings. 
The articles examine the different ways that responsibility, against a backdrop of distributed agency, is constructed by either shortening or expanding chains of liability, including efforts to backdate such claims. In addition, the cases discussed here suggest the need for stronger connections between the anthropology of suffering and the ethical turn in anthropology. More broadly, the special issue points to the value of focusing on legal cases as a rich source of ethnographic information about the relationships between corporations and communities, suggesting promising avenues for future research. The questions raised by the authors about the attribution of responsibility offer a novel way of examining, and potentially critiquing, the power relations that shape the global ecumene. Finally, the case studies show how the demands being made of the law are aspirational in the sense that they do not describe the world as it actually is, but rather how it ought to be. ${ }^{5}$

\section{Acknowledgments}

With thanks to the editors for their invitation to respond to the important issues raised in this collection and Jatin Dua for his valuable suggestions.

Stuart Kirsch is professor of anthropology at the University of Michigan and author of Reverse Anthropology (Stanford University Press, 2006), Mining Capitalism (University of California Press, 2014), and Engaged Anthropology (University of California Press, 2018). His current research project, Transitions: Pathways to a Post-Carbon Future, is funded by the NOMIS foundation in Switzerland. Email: skirsch@umich.edu

\section{Notes}

1. Lucian Bebchuk (1984: 413) argues that 'the discovery requirement will likely increase the probability of settlement'. He indicates that corporations are reluctant to proceed to discovery because of the likelihood of disclosure of information that 'might hurt [them] at trial' (1984: 413), although the potential risks of disclosure to corporate reputations is also an important factor in these decisions.

2. Julia Eckert (forthcoming) refers to this as singularization, by which she means that the result is cut off from various forms of entanglement and influence, although international arbitration might also be described as a process of enclaving legal judgments within restricted domains shielded from the public gaze or evaluation. 
3. This might be compared to the way that the Yonggom people of Papua New Guinea describe the mining company that polluted their river system and destroyed their forests as behaving like a 'corporate sorcerer', emphasizing the underlying social relationship between the two rather treating the environmental impacts as a problem to be resolved by technical means (Kirsch 2006).

4. See Elana Shever (2010) on the gendered face of corporate social responsibility.

5. This parallels Eckert's (forthcoming) recognition of the importance of 'claiming what does not-yet-exist in dominant legal discourse and hence opening up the possibility to think and speak it-and possibly think and speak it into being'.

\section{References}

Arellano-Yanguas, J. (2013), 'Mining and conflict in Peru: Sowing the minerals, reaping a hail of stones', in A. Bebbington (ed), Social Conflict, Economic Development and Extractive Industry: Evidence from South America (New York: Routledge), 89-111.

Bebchuk, L. A. (1984), 'Litigation and settlement under imperfect information', The RAND Journal of Economics 15, no. 3: 404-415.

Benson, P. (2010), 'Safe cigarettes', Dialectical Anthropology 34, no. 1: 49-56. doi:10.2307/29790912

Benson, P. (2014), 'Corporate paternalism and the problem of harmful products', Political and Legal Anthropology Review 37, no. 2: 218-230. doi:10.1111/plar.12071.

Benson, P. and S. Kirsch (2010), 'Capitalism and the politics of resignation'. Current Anthropology 51, no. 4: 459-486. doi:10.1086/653091.

Bose, P. and L. E. Lyons (2010), Cultural Critique and the Global Corporation. (Bloomington: University of Indiana Press).

Broad, R. (2015), 'Corporate bias in the World Bank Group's International Center for Settlement of Investment Disputes: A case study of a global mining corporation suing El Salvador', University of Pennsylvania Journal of International Law 36, no. 4: 851-874.

de la Cadena, M. (2010), 'Indigenous cosmopolitics in the Andes: Conceptual reflections beyond politics', Cultural Anthropology 25, no. 2: 334-370. doi:10.1111/j.1548-1360.2010.01061.x.

Deoancă, A. (2020), "End of the Line: State Infrastructure, Material Ruin, and Precarious Labor along Romanian Railroads." Unpublished Ph.D. dissertation. University of Michigan.

Eckert, J. (forthcoming), 'Entangled hopes: Towards relational coherence', in N. Krisch (ed), Entangled Legalities Beyond the State (Cambridge: Cambridge University Press).

Eckert, J., B. Donahue, Z. Özelm Biner, and C. Strümpell (eds) (2012), Law against the State: Ethnographic Forays into Law's Transformations. (Cambridge: Cambridge University Press).

Kirsch, S. (2001a), 'Lost worlds: Environmental disaster, "culture loss" and the law'. Current Anthropology 42, no. 2: 167-198.

Kirsch, S. (2001b), 'Social networks and compensation claims in Melanesia', Social Anthropology 9, no. 2: 147-163. doi:10.1017/S0964028201000118. 
Kirsch, S. (2006), Reverse Anthropology: Indigenous Analysis of Social and Environmental Relations in New Guinea. (Stanford, CA: Stanford University Press).

Kirsch, S. (2010), 'Sustainable mining', Dialectical Anthropology 34, no. 1: 87-93. doi:10.1007/s10624-009-9113-x.

Kirsch, S. (2014a), Mining Capitalism: The Relationship between Corporations and their Critics. (Oakland: University of California Press).

Kirsch, S. (2014b), 'Imagining corporate personhood: An introduction', Political and Legal Anthropology Review 37, no. 2: 207-217. doi:10.1111/plar.12070.

Kirsch, S. (2018), 'Afterword', in K. Henrard and J. Gilbert (eds), 'Multidisciplinary perspectives on the adjudication of indigenous rights', Erasmus Law Review 11, no. 1: 86-87. doi:10.5553/ELR.000097.

Kirsch, S. (2020), 'Between the devil and the deep blue sea: Objectivity and political responsibility in the litigation of the Exxon Valdez oil spill', Critique of Anthropology 40, no. 4. doi:10.1177/0308275X20959420.

Kirsch, S. and J. Moore (2016), Mining, Corporate Social Responsibility, and Conflict: The El Dorado Foundation and OceanaGold in El Salvador (San Salvador, El Salvador: La Mesa and Institute for Policy Studies), https://ips-dc.org/wp-content/ uploads/2016/03/El-Dorado-Foundation-Report-2016-ENG-lowres.pdf (accessed 12 November 2020).

Ortner, S. (2016), 'Dark anthropology and its others: Theory since the eighties', Hau 6, no. 1: 47-73. doi:10.14318/hau6.1.004.

Rajak, D. (2014), 'Corporate memory: Historical revisionism, legitimation and the invention of tradition in a multinational mining company', Political and Legal Anthropology Review 37, no. 2: 259-280. doi:10.1111/plar.12074

Robbins, J. (2013), 'Beyond the suffering subject: Towards an anthropology of the good', Journal of the Royal Anthropological Institute 19, no. 3: 447-462. doi:10.1111/1467-9655.12044.

Shever, E. (2010), 'Engendering the company: Corporate personhood and the "face" of an oil company in metropolitan Buenos Aires', Political and Legal Anthropology Review 33, no. 1: 26-46. doi:10.1111/j.1555-2934.2010.01091.x.

Strathern, M. (1996), 'Cutting the network', The Journal of the Royal Anthropological Institute 2, no. 3: 517-535.

Torpey, J. (2006), Making Whole What Has Been Smashed: On Reparations Politics. (Cambridge, MA: Harvard University Press). 